\title{
EDITORIAL
}

\section{Pulmonary arterial hypertension: an autoimmune disease?}

\author{
L. Mouthon*, L. Guillevin* and M. Humbert ${ }^{\#}$
}

$\mathbf{P}$ ulmonary arterial hypertension (PAH) is a rare condition that occurs as a consequence of chronic obstruction of small pulmonary arteries due to endothelial cell, vascular smooth muscle cell and fibroblast dysfunction and proliferation [1]. In recent years, major advances have been achieved in the understanding of PAH pathophysiology [1-7]. It has been firmly demonstrated that pulmonary artery endothelial dysfunction leads to chronically impaired production of vasodilators, such as nitric oxide and prostacyclin, along with overexpression of vasoconstrictors such as endothelin-1 [8-10]. Moreover, genetic studies have shown that germline mutations in the gene coding for bone morphogenetic protein receptor type II (BMPR2) certainly play a critical role in a proportion of patients with familial and idiopathic PAH $[2,3]$. Immune disturbances are also believed to contribute to PAH [5]. This is particularly clear in PAH related to connective tissue diseases $[5,11]$. In addition, there is a long standing association between autoimmunity and $\mathrm{PAH}$ of various origins including idiopathic PAH. However, it remains uncertain how autoimmune mechanisms contribute to the pathogenesis of PAH. In the current issue of the European Respiratory Journal, NicolLs et al. [7] review available data documenting the association of autoimmunity and PAH and speculate on the possible role of autoimmune injury in the pathogenesis of the disease.

$\mathrm{PAH}$ is a common complication of autoimmune diseases, such as systemic sclerosis (SSc), mixed connective tissue disease and systemic lupus erythematosus [11, 12]. SSc is characterised by excessive collagen deposition in the dermis and internal organs, vascular hyper-reactivity and obliterative microvascular phenomena [13]. Recent studies based on right-heart catheterisation have established that at least $8-12 \%$ of SSc patients display PAH $[14,15]$. When lung tissue is available, it appears that pulmonary arteriopathy in patients with connective tissue disease-associated PAH has similarities with that described in idiopathic PAH $[5,16]$. These resemblances suggest that similar mechanisms may contribute to both conditions. Besides medial hypertrophy, intimal "onion bulb" lesions and characteristic plexiform lesion, CoOL et al. [17] have

\footnotetext{
*Paris-Descartes University, Faculty of Medicine, Cochin Hospital, Paris, and \#UPRES-EA 2705 Pneumology Dept and French National Reference Centre for Pulmonary Hypertension, Antoine Béclère Hospital, Clamart, France.

CORRESPONDENCE: L. Mouthon, Laboratoire d'Immunologie, Pavillon Gustave Roussy, 4e étage, Université Paris-Descartes, 8 rue Méchain, 75014, Paris, France. Fax: 33 144412546. E-mail: luc.mouthon@cch.aphp.fr
}

reported that in patients with SSc-related PAH, mononuclear inflammatory cells surrounded vascular sites of plexiform growth, but not uninvolved vessels or extravascular lung structure. Interestingly, TUDER et al. [18] have also reported that perivascular inflammatory infiltrates with macrophages and lymphocytes could be detected in the range of occlusive lesions in idiopathic PAH.

A number of auto-antibodies have been identified in the serum of SSc patients, including disease specific antibodies, such as anti-centromere, anti-topoisomerase 1 and anti-RNA-polymerase Ab. Nonspecific antibodies, such as anti-fibrillarin (U3 small nucleolar RNP), anti-fibrillin 1, anti-Th/To, anti-PM/Scl, antimitochondrion, anti-fibroblast and anti-endothelial cell antibodies, have also been identified in the serum of SSc patients [19]. As stated by Nicolls et al. [7], anti-endothelial cell antibodies could play a role in the pathogenesis of SSc, since they can activate endothelial cells, induce the expression of adhesion molecules [20], and trigger apoptosis in the presence of natural killer cells [21]. Moreover, in in vitro experiments, auto-antibodies from patients with connective tissue diseases (anti-U1-RNP, anti-dsDNA) induced an upregulation of adhesion molecules (intracellular adhesion molecule-1, endothelial leukocyte adhesion molecule-1), as well as major histocompatability complex class II molecules on human pulmonary endothelial cells, suggesting that such an inflammatory process could lead to proliferative and inflammatory pulmonary vasculopathy [22]. Finally, some patients with severe PAH associated with systemic lupus erythematosus have improved their conditions with immunosuppressive therapy, emphasising the relevance of inflammation and autoimmunity in this subset of patients [23]. However, there are differences in the pathogenesis of idiopathic and connective tissue disease associated PAH that preclude their assimilation. For instance, to date, attempts to detect germline BMPR2 mutations have failed in SScassociated PAH [24] and the genetic susceptibility of both groups of patients to develop PAH probably differs. Moreover, other investigators speculated that antibodies to BMPRII could trigger PAH in patients with mixed connective tissue diseases. However, these antibodies failed to be detected in any of the patients [25]. Finally, anticentromere antibodies are associated with the occurrence of $\mathrm{PAH}$ in SSc patients, but their pathogenic role is not clearly established.

Nicolls et al. [7] propose that germline BMPR2 mutations might be responsible for regulatory $\mathrm{T}$-cell defects and 
predispose to the occurrence of PAH. Thus, in a manner analogous to patients developing $\mathrm{PAH}$ because of acute infarction ramapril emphysema gene mutations [26], they propose that germline BMPR2 mutations may, in part, promote $\mathrm{PAH}$ because they lead to a fundamental defect in peripheral immune tolerance and favour the rise of auto-antibodies. This would explain why a significant proportion of idiopathic $\mathrm{PAH}$ patients without immunodeficiency or other associated systemic diseases have evidence of autoimmunity and/or active inflammation including detection of circulating autoantibodies [27, 28]. This autoimmune pathogenetic link is also supported by studies suggesting a close association between idiopathic PAH and autoimmune thyroid disease, including Grave's disease or Hashimoto thyroiditis [29, 30]. Of interest, we have recently reported the presence of anti-endothelial cell antibodies in patients displaying idiopathic PAH [31]. We have observed that immunoglobulin (Ig)G antibodies from patients with idiopathic PAH bind to $36 \mathrm{kDa}$ and $60 \mathrm{kDa}$ bands in endothelial cell extracts with a higher intensity than IgG from SSc patients with PAH and healthy controls. In these experiments, serum IgG from limited cutaneous SSc patients with $\mathrm{PAH}$, but not from idiopathic $\mathrm{PAH}$ patients, bound to two major $75 \mathrm{kDa}$ and $85 \mathrm{kDa}$ bands in endothelial cells extracts, suggesting their binding to different target antigens [31]. We recently further identified that IgG anti-fibroblast antibodies are also present in the serum of patients with idiopathic PAH and SSc associated PAH [32]. However, the target antigens, the potential pathogenetic role of these antibodies and their predictive value in patients at risk to develop PAH, such as SSc patients and patients with a familial history of $\mathrm{PAH}$, needs to be investigated. Indeed, the detection of auto-antibodies in a given condition is not sufficient to document an autoimmune mechanism. According to ROSE and BONA [33], different levels of evidence can be obtained to assess the autoimmune nature of a disease. Theses are: 1) direct evidence from transfer of pathogenic antibody or pathogenic T cells; 2) indirect evidence based on reproduction of the autoimmune disease in experimental animals; and 3) circumstantial evidence from clinical clues.

In conclusion, we can easily state here that only circumstantial evidence has been obtained in the case of pulmonary arterial hypertension. Nevertheless, the data reviewed by Nicolls et al. [7] in this issue of the European Respiratory Journal plead in favour of the relevance of immune disturbances in pulmonary arterial hypertension of various origins [23], and it is likely that a better understanding of the exact role of autoimmunity and inflammation will help defining novel therapeutic targets in this devastating condition.

\section{REFERENCES}

1 Humbert M, Morrell NW, Archer SL, et al. Cellular and molecular pathobiology of pulmonary arterial hypertension. J Am Coll Cardiol 2004; 43: Suppl. 12, 13S-24S.

2 Lane KB, Machado RD, Pauciulo MW, et al. Heterozygous germline mutations in BMPR2, encoding a TGF-beta receptor, cause familial primary pulmonary hypertension. The International PPH Consortium. Nat Genet 2000; 26: 81-84.
3 Thomson JR, Machado RD, Pauciulo MW, et al. Sporadic primary pulmonary hypertension is associated with germline mutations of the gene encoding BMPR-II, a receptor member of the TGF-beta family. J Med Genet 2000; 37: 741-745.

4 Trembath RC, Thomson JR, Machado RD, et al. Clinical and molecular genetic features of pulmonary hypertension in patients with hereditary hemorrhagic telangiectasia. N Engl J Med 2001; 345: 325-334.

5 Dorfmuller P, Perros F, Balabanian K, Humbert M. Inflammation in pulmonary arterial hypertension. Eur Respir J 2003; 22: 358-363.

6 Chaouat A, Coulet F, Favre C, et al. Endoglin germline mutation in a patient with hereditary haemorrhagic telangiectasia and dexfenfluramine associated pulmonary arterial hypertension. Thorax 2004; 59: 446-448.

7 Nicolls M, Taraseviciene-Stewart L, Voelkel N. Autoimmunity in the pathogenesis of pulmonary hypertension. Eur Respir J 2005; 26: 1110-1118.

8 Christman BW, McPherson CD, Newman JH, et al. An imbalance between the excretion of thromboxane and prostacyclin metabolites in pulmonary hypertension. N Engl J Med 1992; 327: 70-75.

9 Giaid A, Yanagisawa M, Langleben D, et al. Expression of endothelin-1 in the lungs of patients with pulmonary hypertension. N Engl J Med 1993; 328: 1732-1739.

10 Giaid A, Saleh D. Reduced expression of endothelial nitric oxide synthase in the lungs of patients with pulmonary hypertension. N Engl J Med 1995; 333: 214-221.

11 Hoeper MM. Pulmonary hypertension in collagen vascular disease. Eur Respir J 2002; 19: 571-576.

12 Simonneau G, Galie N, Rubin LJ, et al. Clinical classification of pulmonary hypertension. J Am Coll Cardiol 2004; 43: Suppl. 12, 5S-12S.

13 Clements PJ. Systemic sclerosis (scleroderma) and related disorders: clinical aspects. Baillieres Best Pract Res Clin Rheumatol 2000; 14: 1-16.

14 Mukerjee D, St George D, Coleiro B, et al. Prevalence and outcome in systemic sclerosis associated pulmonary arterial hypertension: application of a registry approach. Ann Rheum Dis 2003; 62: 1088-1093.

15 Hachulla E, Gressin V, Guillevin L, et al. Early detection of pulmonary arterial hypertension in systemic sclerosis: a French nationwide prospective multicenter study. Arthritis Rheum 2005; (In press).

16 Pietra GG, Capron F, Stewart S, et al. Pathologic assessment of vasculopathies in pulmonary hypertension. J Am Coll Cardiol 2004; 43: Suppl. 12, 25S-32S.

17 Cool CD, Kennedy D, Voelkel NF, Tuder RM. Pathogenesis and evolution of plexiform lesions in pulmonary hypertension associated with scleroderma and human immunodeficiency virus infection. Hum Pathol 1997; 28: 434-442.

18 Tuder RM, Groves B, Badesch DB, Voelkel NF. Exuberant endothelial cell growth and elements of inflammation are present in plexiform lesions of pulmonary hypertension. Am J Pathol 1994; 144: 275-285.

19 Tamby MC, Chanseaud Y, Guillevin L, Mouthon L. New insights into the pathogenesis of systemic sclerosis. Autoimmun Rev 2003; 2: 152-157.

20 Carvalho D, Savage CO, Black CM, Pearson JD. IgG antiendothelial cell autoantibodies from scleroderma 
patients induce leukocyte adhesion to human vascular endothelial cells in vitro. Induction of adhesion molecule expression and involvement of endothelium-derived cytokines. J Clin Invest 1996; 97: 111-119.

21 Bordron A, Dueymes M, Levy Y, et al. The binding of some human antiendothelial cell antibodies induces endothelial cell apoptosis. J Clin Invest 1998; 101: 2029-2035.

22 Okawa-Takatsuji M, Aotsuka S, Fujinami M, Uwatoko S, Kinoshita M, Sumiya M. Up-regulation of intercellular adhesion molecule-1 (ICAM-1), endothelial leucocyte adhesion molecule-1 (ELAM-1) and class II MHC molecules on pulmonary artery endothelial cells by antibodies against U1-ribonucleoprotein. Clin Exp Immunol 1999; 116: 174-180.

23 Sanchez O, Humbert M, Sitbon O, Simonneau G. Treatment of pulmonary hypertension secondary to connective tissue diseases. Thorax 1999; 54: 273-277.

24 Morse J, Barst R, Horn E, Cuervo N, Deng Z, Knowles J. Pulmonary hypertension in scleroderma spectrum of disease: lack of bone morphogenetic protein receptor 2 mutations. J Rheumatol 2002; 29: 2379-2381.

25 Satoh T, Kimura K, Okano Y, Hirakata M, Kawakami Y, Kuwana M. Lack of circulating autoantibodies to bone morphogenetic protein receptor-II or activin receptor-like kinase 1 in mixed connective tissue disease patients with pulmonary arterial hypertension. Rheumatology (Oxford) 2005; 44: 192-196.

26 Korniszewski L, Kurzyna M, Stolarski B, Torbicki A, Smerdel A, Ploski R. Fatal primary pulmonary hypertension in a 30-yr-old female with APECED syndrome. Eur Respir J 2003; 22: 709-711.

27 Isern RA, Yaneva M, Weiner E, et al. Autoantibodies in patients with primary pulmonary hypertension: association with anti-Ku. Am J Med 1992; 93: 307-312.

28 Morse JH, Antohi S, Kasturi K, et al. Fine specificity of anti-fibrillin-1 autoantibodies in primary pulmonary hypertension syndrome. Scand J Immunol 2000; 51: 607-611.

29 Chu JW, Kao PN, Faul JL, Doyle RL. High prevalence of autoimmune thyroid disease in pulmonary arterial hypertension. Chest 2002; 122: 1668-1673.

30 Badesch DB, Wynne KM, Bonvallet S, Voelkel NF, Ridgway C, Groves BM. Hypothyroidism and primary pulmonary hypertension: an autoimmune pathogenetic link? Ann Intern Med 1993; 119: 44-46.

31 Tamby MC, Chanseaud Y, Humbert M, et al. Antiendothelial cell antibodies in idiopathic and systemic sclerosis associated pulmonary arterial hypertension. Thorax 2005; 60: 765-772.

32 Tamby M, Chanseaud Y, Humbert M, et al. IgG from patients with pulmonary arterial hypertension (PAH) associated with systemic sclerosis (SSc) and from patients with primary PAH express distinct reactivity profiles with normal human fibroblasts antigens. Ann Rheum Dis 2004; 63: Suppl. 1, 346

33 Rose NR, Bona C. Defining criteria for autoimmune diseases (Witebsky's postulates revisited). Immunol Today 1993; 14: 426-430. 